\title{
PRIMJENA ANALITIČKIH METODA U POSTUPCIMA AUTENTIFIKACIJE POLJOPRIVREDNIH I PREHRAMBENIH PROIZVODA
}

\author{
Kristina Gvozdanović, Polona Margeta, V. Margeta
}

\begin{abstract}
Sažetak
Autentifikacija proizvoda služi za dokazivanje sastava i podrijetla poljoprivrednih i prehrambenih proizvoda. Republika Hrvatska ima veliki broj poljoprivrednih i prehrambenih proizvoda koji su zbog specifičnih organoleptičkih, tehnoloških i prehrambenih specifičnosti deklarirani kao proizvodi visoke vrijednosti te zaštićeni oznakom izvornosti, zemljopisnog podrijetla ili zajamčeno tradicionalnog specijaliteta. Provođenje postupka autentifikacije predstavlja multidisciplinarni postupak koji uključuje analitičke metode kombinirane s informatikom, matematikom i statistikom, a sve s ciljem dobivanja što točnijih i pouzdanijih podataka kako bi se mogao donijeti zaključak o podrijetlu i sastavu proizvoda. Zanimanje javnosti za konzumiranjem kvalitetne i sigurne hrane dovelo je do brzog razvoja metoda za autentifikaciju proizvoda. U analitičke metode analize ubrajaju se molekularne metode analize, kromatografske metode, spektrometrijske metode i imunološke metode. U radu su opisane analitičke metode koje se primjenjuju u postupcima dokazivanja izvornosti, zemljopisnog podrijetla ili tradicijskog specijaliteta proizvoda u svijetu
\end{abstract}

Ključne riječi: autentifikacija, analitičke metode, zaštita proizvoda, poljoprivredni i prehrambeni proizvodi

\section{Uvod}

Autentifikacija pasmine i proizvoda od velike je važnosti za proizvođače zbog toga što se ime pasmine često koristi kao naziv brenda određenog proizvoda što utječe na marketing tog proizvoda te njegovu potrošnju (Fernandez i sur., 2004.). Sustav za registraciju proizvoda s oznakom izvornosti zemljopisnog podrijetla uveden je tijekom 1992. godine od strane Europske Unije, a s ciljem zaštite proizvoda od narušavanja njegovog izgleda i kvalitete. Jedna od pretpostavki zaštite je i stvaranje identiteta i prepoznatljivosti regije iz koje proizvod potječe. Razvoj analitičkih metoda ide u smjeru implementacije bržih i jednostavnih načina analize prehrambenih proizvoda s ciljem autentifikacije i dokazivanja podrijetla proizvoda.

Cilj rada je prikazati razvoj analitičkih metoda koje se primjenjuju u postupcima autentifikacije prehrambenih proizvoda u svijetu. Prikazujući prednosti i nedostatke te mogućnosti daljnjeg razvoja postojeće metodologije, dobiva se uvid u budućnost i važnost analitičkih metoda u području sigurnosti prehrambenih proizvoda te njihovu moguću primjenu u postupcima analize proizvoda dobivenih od hrvatskih autohtonih pasmina svinja.

Dr.sc. Kristina Gvozdanović, dr.sc. Polona Margeta, doc.dr.sc. Vladimir Margeta - Sveučilište Josipa Jurja Strossmayera u Osijeku, Poljoprivredni fakultet u Osijeku, Vladimira Preloga 1, 31000 Osijek

Dopisni autor/Corresponding author: Kristina Gvozdanović; e-mail: kgvozdanovic@pfos.hr 


\section{Postupak autentifikacije}

Oznaka izvornosti određena je regijom, odnosno specifičnim područjem na kojem se uzgajaju životinje koje se kasnije koriste za proizvodnju prehrambenih proizvoda. Kvaliteta i karakteristika dobivenih proizvoda, tehnologija proizvodnje i okolišni faktori uvelike utječu na specifičnost proizvedenog prehrambenog proizvoda. Oznaka zemljopisnog podrijetla opisuje prehrambene i poljoprivredne proizvode koji potječu sa određenog područja ili države sa specifičnim karakteristikama. Nadalje, proizvodnja i prerada takvog proizvoda mora se odvijati na navedenom području. Zajamčeno tradicionalni specijalitet je proizvod kod kojeg se naglasak stavlja na tradiciju proizvodnje ili sastava određenog proizvoda, a manje na područje na kojem je proizvedeno (slika 1.).
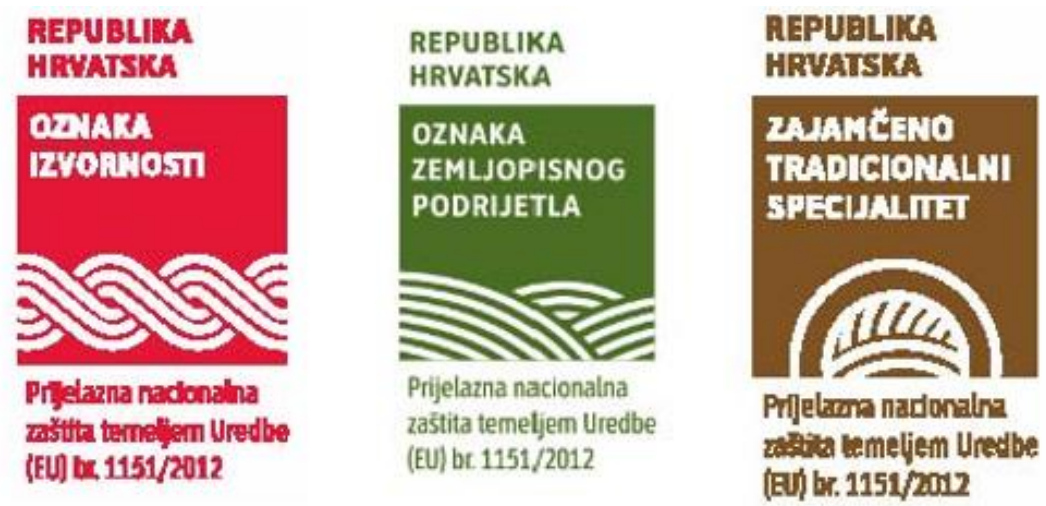

Slika 1. Oznaka izvornosti, zemljopisnog podrijetla i zajamčeno tradicionalnog specijaliteta (MPS, 2016)

Figure 1 Designations of origin, geographical indications and traditional specialties guaranteed (MPS, 2016.)

Osnovna pretpostavka zaštite je stvaranje prepoznatljivosti regije iz koje proizvod potječe. U Hrvatskoj postoji Pravilnik o oznakama izvornosti i oznakama zemljopisnog podrijetla poljoprivrednih i prehrambenih proizvoda (NN 88/09, 53/10, 46/11). Navedeni pravilnik je proizašao iz Zakona o oznakama izvornosti, oznakama zemljopisnog podrijetla i oznakama tradicionalnog izgleda poljoprivrednih i prehrambenih proizvoda (NN 84/08, 75/09, 20/10), a koji je preuzet iz Uredbe Vijeća EU 510/06 (EZ br. 510/2006) o zaštiti zemljopisnih oznaka i oznaka podrijetla poljoprivrednih i prehrambenih proizvoda. Pravilnikom je opisan postupak dodjeljivanja oznake izvornosti i zemljopisnog podrijetla te cijeli postupak zaštite i ocjene izvornosti. Ukoliko se proizvod želi zaštititi zaštićenim oznakama izvornosti ili zemljopisnog podrijetla mora se izraditi specifikacija proizvoda koja mora biti u skladu s navedenim proizvodom. Tijekom zadnjih desetljeća mesna industrija je razvila sustav praćenja proizvoda od farme do krajnjeg potrošača s ciljem očuvanja njegove zaštite i biosigurnosti. Spoznaja o patvorenju hrane, neadekvatnoj proizvodnji i analizi došla je do izražaja tijekom 2013. godine kada se ustanovilo da je određenim proizvodima dodavano konjsko meso. Navedeni događaj doveo je do povećanja svijesti o važnosti proizvodnje kvalitetne i sigurne hrane. Postupak 
autentifikacije mesa $\mathrm{i}$ mesnih proizvoda daje uvid u točnost $\mathrm{i}$ istinitost podataka koje proizvođači daju o nekom proizvodu, misleći pritom na njegov kemijski sastav, podrijetlo ili tehnologiju proizvodnje (Rodriguez-Ramirez i sur., 2011.). Prema Ballin (2010.) metode autentifikacije se dijele s obzirom na podrijetlo mesa, procese prerade mesa, dodatak sastojaka koji nisu animalnog podrijetla te proces zamjene mesa drugim sastojcima. Određivanje podrijetla nekog proizvoda predstavlja temelj provođenja postupka autentifikacije. Autentifikacija je od posebnog značaja za one proizvode koji su dobiveni od sirovine autohtonog podrijetla, misleći pritom na meso autohtonih pasmina domaćih životinja. Danas su u svijetu posebno razvijeni postupci autentifikacije njemačkih autohtonih pasmina svinja (Schwäbisch-Hällisches), španjolskih autohtonih pasmina svinja (Iberijska svinja), talijanskih autohtonih pasmina svinja (Cinta Sense, Nera Siciliana, Casertana) i portugalskih autohtonih pasmina svinja (Alentejano pasmina). S obzirom na to da Hrvatska ima dvije autohtone pasmine svinja - crnu slavonsku svinju i turopoljsku svinju, važno je razviti i implementirati postupak autentifikacije i na proizvode dobivene od navedenih pasmina. Prvi korak u provođenju toga postupka bila bi izrada specifikacije te zaštita mesa autohtonih pasmina. Pri izradi specifikacije proizvoda uzima se u obzir naziv odnosno ime proizvoda, opis poljoprivrednog ili prehrambenog proizvoda, definicija zemljopisnog područja, dokaz da poljoprivredni ili prehrambeni proizvod potječe iz određenog zemljopisnog područja, opis metode dobivanja poljoprivrednog ili prehrambenog proizvoda i, ako je primjereno, autentične i nepromjenljive lokalne metode, povezanost između kakvoće ili karakteristika poljoprivrednog ili prehrambenog proizvoda i zemljopisnog okruženja, povezanost između specifične kakvoće, ugleda ili neke druge karakteristike poljoprivrednog ili prehrambenog proizvoda i zemljopisnog podrijetla te bilo koja specifična pravila označivanja za taj poljoprivredni ili prehrambeni proizvod (EZ br. 510/2006). Trenutno je u izradi specifikacija za poljoprivredni ili prehrambeni proizvod za zaštitu naziva oznakom izvornosti, oznakom zemljopisnog podrijetla ili zajamčeno tradicionalnog specijaliteta, tj. specifikacija za zaštitu mesa crne slavonske svinje.

\section{Analitičke metode}

Tijekom posljednjih godina došlo je do razvoja niza analitičkih metoda primjenom kojih je moguće identificirati strane supstance u proizvodima namijenjenima ljudskoj prehrani. Navedene metode je moguće implementirati u postupke analize proizvoda dobivenih od autohtonih pasmina domaćih životinja neovisno o području uzgoja. Navedenim postupkom pojedine analitičke metode želi se zaštiti proizvod od mogućeg patvorenja od strane proizvođača te istovremeno zaštiti krajnjeg potrošača od mogućih prijevara na tržištu prehrambenih proizvoda. Metode autentifikacije mogu biti konvencionalne ili molekularne. Konvencionalne metode analize, temeljene na analizi organoleptičkih svojstava, provodile su se pomoću mikroskopa ili analitičkih vagi, no zbog nepouzdanosti te nemogućnosti određivanja podrijetla svih sastojaka u proizvodima, ovakav tip analize je zamijenjen molekularnim metodama (Ali i sur., 2012.). Tek razvojem sustava analize koji se temelje na analizi DNK dobio se stvarni uvid u podrijetlo proizvoda. Odabir metode i načina autentifikacije ovisi o očekivanim rezultatima i razini informativnosti. Sustavi se temelje na analizi endogene DNK, no noviji načini uključuju i analizu egzogene DNK (Fontanesi, 2009.). 


\section{Molekularne metode}

Mogućnosti analize DNK te poznavanje genoma velikog broja organizama predstavlja jednu od najvažnijih promjena koje su se dogodile tijekom zadnjih deset godina, a imale su značajan utjecaj na razvoj metoda i postupaka autentifikacije te sljedivosti (Sforza, 2013.). Razvoj metoda sinteze i analize DNK imao je veliki utjecaj na razvoj postupaka identifikacije pojedinih životinjskih vrsta što je posljedično utjecalo na implementaciju te razvoj postupaka autentifikacije proizvoda. Nekoliko je načina autentifikacije proizvoda molekularno-genetskim metodama. Prvi se temelji na provođenju lančane reakcije polimerazom (engl. polymerase chain reaction, PCR) koju slijede gel elektroforeza i hibridizacija sa specifičnim sondama. Zatim slijedi identifikacija pojedinih DNK fragmenata pomoću specifičnih sondi, dok je posljednja metoda sekvenciranje DNK (Sforza, 2013.). Kary Mullis prvi je razvio PCR reakciju koja predstavlja osnovu analize genetskog materijala (Saiki i sur., 1985.). Primjena PCR metode kombinirane s tehnologijom molekularnih markera prvi je puta primijenjena tijekom 1989. godine analizom mikrosatelita i minisatelita (Weber i May, 1989.). Daljnja provjera PCR produkata može biti u vidu sekvenciranja PCR produkata, simultanog umnažanja više fragmenata s različitim probama (eng. multiplex PCR), analize polimorfizma dužine jednog fragmenta (PCR-RFLP), DNK čipova, PCR specifičnog za vrstu i analize slučajno umnoženog polimorfnog fragmenta (PCR-RAPD) (Sumathi i sur., 2015.; Veselenak i sur., 2015.). Molekularne markere definiramo kao DNK sekvence koje se nalaze na specifičnim mjestima u genomu, a nasljeđuju se Mendelovim zakonima s jedne generacije na drugu. Mogu biti genetski markeri čija se analiza temelji na hibridizaciji, tj. na analizi restrikcijskih fragmenata duljine polimorfizma (eng. restriction fragment length polymorphisms, RFLP) ili markeri kojima je osnova analize primjena PCR metode. Molekularni markeri koji se koriste pri autentifikaciji proizvoda su polimorfizam dužine jednog fragmenta (RFLP) (Kumar i sur., 2014.), mikrosatelitski markeri (Fontanesi i sur., 2014.; Fontanesi i sur., 2016.), mitohondrijska DNK (mtDNK) (Murugaiah i sur., 2015.; Ni'mah i sur., 2016.) i polimorfizam jednog nukleotida (SNP) (Corrado, 2016.). RFLP markeri se temelje na hibridizaciji, tj. obilježenim probama gena koji su hibridizirani na filter membranu s restrikcijskim enzimima te razdvojeni gel elektroforezom i prebačeni na membranu Southern blot metodom. Rezultati analize su vidljivi u obliku različitih hibridiziranih bendova. Osnovne karakteristike mikrosatelitskih markera su kodominantan način nasljeđivana, visoka zastupljenost po genomu te visoki stupanj polimorfizma. Predstavljaju kratke sekvence do 6 nukleotidnih ponavljanja. Njihova primjena je u postupcima autentifikacije, tj. genetskim analizama unutar i između populacija, izrađivanju genskih karti, identifikaciji životinja te rekonstrukciji filogenetskih odnosa populacija (Crooijmans i sur., 2008.; Pardo, i sur., 2015.). Mitohondrijska DNK se koristi kao molekularan marker u populacijskog i evolucijskoj biologiji te predstavlja izvor genetske varijabilnosti. Njezine karakteristike su visoki stupanj mutacije u odnosu na jezgrinu DNK, jednostavna organizaciju i izolacija, nedostatak rekombinacija i nasljeđivanje putem majke (Galtier i sur., 2009.). Najbolje istražen gen mitohondrijske DNK je citokrom b. Kocher i sur. (1989.) su prvi koristili ovaj gen za identifikaciju različitih vrsta životinja u uzorcima mesa. Upravo je primjena ovog gena postala standardna metoda takvog tipa analize. Polimorfizam jednog nukleotida je najčešća varijacija koja se javlja u fragmentu DNK. Nukleotid je polimorfan ukoliko postoji u najmanje dvije inačice uz uvjet da je učestalost češće inačice 
manja od 99\%. Njihova primjena je u određivanju individualne sljedivosti, određivanju roditeljskih jedinki te utvrđivanju bioraznolikosti vrsta (Farag i sur., 2010.). Do sada otkriveni SNPovi se nalaze u bazi http://www.ncbi.nlm.nih.gov/SNP koja je javno dostupna. Obzirom na to da metode temeljene na analizi DNK ovise o provođenju PCR reakcije te uzorcima DNK koji se analiziraju, možemo govoriti o genomskim metodama za razliku od proteina koji mogu djelovati kao markeri te pripadaju sferi proteomskih metoda (Ali i sur., 2014.). Pod pojmom proteomike podrazumijevamo znanstvenu disciplinu koja se bavi strukturom i građom proteina te njihovim međusobnim odnosnima. Pojam proteoma definirao je Wilkins (1996.), a on kaže da je to set proteina neke stanice u određenoj fazi zajedno sa svim izoformama i modificiranim proteinima. Važnost proteomike u procesu autentifikacije ogleda se u potrazi za novim i specifičnim proteinima i peptidima. Sun i sur. (2014.) navode prednosti i nedostatke primjene genomske i proteomske metodologije istraživanja. Uspoređujući metode koje se temelje na genomskim analizama i proteomskim analizama može se uočiti da se genomskim pristupom umnažaju i analiziraju nukleotidni materijali dok proteomika identificira specifične proizvode DNK, odnosno proteine. Nadalje osjetljivost navedenih metoda je vrlo visoka. Kromatografija i spektroskopija su metode koje se temelje na analizi proteina. Ali i sur. (2014.) navode da je jedan od nedostataka primjene ove metode promjena strukture proteina koje se mogu dogoditi tijekom izvođenja postupka analize što utječe na rezultate analize. Osim toga, imunopretrage koje se temelje na upotrebi antitijela protiv specifičnih proteina često puta budu suprimirane djelovanjem unakrsnih reakcija koje se javljaju zbog srodnosti vrsta. Genomika i proteomika svoju primjenu imaju u analizi i autentifikaciji raznih uzoraka koji mogu biti podrijetlom od genetski modificirane organizama, morskih organizama, halal ili košer proizvoda, mesa divljači te proizvoda od različitih vrsta domaćih životinja. Nadalje, navedene metode se konstantno razvijaju i unaprjeđuju, a najbolji primjeri toga su PCR polimorfizmi konformacije jednog lanca (PCR-SSCP), DNK fingerprint, peptidi nukleinskih kiselina (PNA) i polimorfizam slučajno umnožene DNK (RAPD) (Sforza, 2013.).

\section{Kromatografske metode}

Kromatografska analiza omogućuje brzo i pouzdano razdvajanje kemijski sličnih supstanci te označava jednu od najvažnijih metoda koje se primjenjuju u postupku analize hrane. Kromatografija označava metodu koja se temelji na adsorpciji i dijeljenju spojeva između mobilne i stacionarne faze. Tako je primjerice kod plinske kromatografije i plinsko-tekućinske kromatografije mobilna faza plin. Obzirom na to da se u prehrambenim proizvodima nalazi veliki broj različitih tvari (peptida, lipida, ugljikohidrata, aminokiselina, masnih kiselina i aditiva) primjena kromatografske analize mora u skladu sa sastavom proizvoda (Ibáñez i sur., 2014.). Navedeni sastojci su različite prirode te mogu biti od malih organskih molekula do makromolekula, a obzirom na polarnost mogu biti od skupine nepolarnih do izrazito polarnih spojeva. Princip analize je stvaranje jedinstvenih kemijskih otisaka uz pomoć kojih je moguće identificirati analitičke razlike između uzoraka ili identificirati specifične markere. Temelj za provođenje analize je činjenica da se navedeni sastojci kemijski vrlo razlikuju ovisno o veličini i polarnosti. Plinska kromatografija i tekućinska kromatografija su kromatografske metode kojima je moguće autentificirati proizvode, a zajedno s masenom spektrometrijom zaokružuju metode razvijene obzirom na kompleksnost sastava proizvoda te zahtjeve potrošača. Ovim tipovima analize moguće je odvojiti i identificirati gotovo sve molekule koje 
su prisutne u uzorcima hrane (Reid i sur., 2006.). Osnova rada tekuće kromatografije su veličina molekule, polarnost i električni naboj. Najčešće se koristi pri analizi ugljikohidrata, proteina, vitamina, fenolnih spojeva, aminokiselina i pigmenata. Nedostatak rada tekuće kromatografije je u tome što je nužno ekstrahirati analitičke podatke povezane s pojedinim komponentama što zahtjeva utrošak dodatnog rada u laboratorijima (Fanali i sur., 2017.). Primjena plinske kromatografije moguća je samo kod lako hlapljivih spojeva. Ona se najčešće kombinira s metodom masene spektrometrije. Upravo masena spektrometrija daje strukturne informacije koje nije moguće dobiti drugim načinima analize. Prednosti korištenja plinske kromatografije su osjetljivost metode, ponovljivost, veliki kapacitet razdvajanja, raznovrsnost te mnogostruka primjenjivost (Littlewood, 2013.). Tekućinska kromatografija visoke djelotvornosti (engl. high - performance liquid chromatography, HPLC) jedna je od najzastupljeniji metoda analize koja se široko primjenjuje u postupcima autentifikacije proizvoda (Mayer, 2013.). Analiza pomoću HPLC-a omogućava analizu polarnih i nepolarnih sastojaka u uzorcima (Sun i sur., 2008.). Kromatografske metode najčešće se koriste pri autentifikaciji meda, vina, ulja, kave, mlijeka, sira i gljiva. Provođenje analize temelji se na određivanju masnih kiselina, triglicerida, sterola, ugljikovodika, tokoferola i alkohola, odnosno onih spojeva koji su razlog specifičnog profila proizvoda (Di Stefano i sur., 2012.).

\section{Spektrometrijske metode}

Nekoliko je čimbenika o kojima ovisi odabir metode analize, a to su kemijski sastav i priroda analiziranih uzoraka, potrebno vrijeme za dobivanje rezultata, oprema potrebna za izvođenje analize te točnost rezultata koji će se dobiti provedenim postupkom. Infracrvena i nuklearna magnetska rezonanca su spektrometrijske metode koje se primjenjuju u postupcima autentifikacije proizvoda. Infracrvena spektroskopija je brza i nedestruktivna metoda koja omogućava analizu velikog broja uzoraka (Downey i sur., 1996.). Meurens (2003.) navodi da je ovo najzastupljenija metoda spektroskopije. To je instrumentalna metoda pomoću koje je moguće identificirati funkcionalne skupine u molekuli. Radi u rasponu elektromagnetnog zračenja od 2,5-15,0 mm. Temelji se na apsorpciji svjetla čija se frekvencija podudara $\mathrm{s}$ frekvencijom vibracija veza u molekuli.

Nuklearna magnetska spektroskopija je brza i pouzdana metoda pomoću koje je moguća analiza velikog broja uzoraka. Temelj ove metode čini apsorpcija energije jezgre u području radiovalova. Ona predstavlja metodu pogodnu za analizu spektroskopskih i strukturnih informacija velikog broja molekularnih spojeva. Uz malu količinu uzorka moguće je postići vrlo precizne rezultate. Upravo je ova visoka osjetljivost smatrana glavnim ograničenjem nuklearne magnetne spektroskopije. Nuklearnom magnetnom spektroskopijom je moguće prikupiti metaboličke profile koji se zatim koriste za provjeru autentičnosti proizvoda. Njezina primjena u području prehrambenih proizvoda uključuje analizu mliječnih proizvoda, mesa, ribe, voća, biljnih i ribljih ulja, kave i čaja. Navedene metode se kombiniraju s kemometrijom koja zapravo predstavlja spoj matematičkih i statističkih metoda pomoću kojih se može dobiti informacija o kemijskom sastavu analiziranih uzoraka (Denezis i sur., 2016.).

\section{Imunološke metode}

Imunološke metode se temelje na analizi specifičnih reakcija koje se odvijaju između protutijela i antigena, odnosno na sposobnosti antitijela da prepoznaju trodimenzijsku 
strukturu i pokrenu biokemijsku reakciju. Njihova primjena je raznolika, od polja imunologije do identifikacije različitih drugih molekula kao što su proteini, malih organskih molekula ili složenih spojeva prisutnih u uzorcima hrane i prehrambenih spojeva (Nilsen, 2010.). Imunološke metode su brze, visoko specifične i osjetljive te jednostavne za izvođenje (Lefkovits i Pernis, 2014.). To su razlozi zbog kojih su postale prihvatljive u postupcima identificiranja različitih sastojaka u prehrambenim proizvodima. Proizvodna specifičnih antitijela je ključni korak implementacije imunoloških metoda analize obzirom na to da se takvi spojevi koriste za hvatanje specifičnih antigena (Asensio i sur., 2008.). Autentifikacija proizvoda imunološkim metodama uključuje identifikaciju i dokazivanje osteokalcina u mesu i koštanom brašnu, detekciju melamina i goveđeg IgG u mlijeku te identifikaciju proteina soje u mesnim proizvodima. Najzastupljenija imunološka metoda koja se danas koristi u procesima autentifikacije proizvoda je ELISA (engl. enzyme-linked immunosorbent assay, ELISA) (Hsieh i sur., 2015.). Otkriće vezanja antigena ili protutijela sa čvrstom podlogom te nemogućnost njihovog ispiranja puferiranom fiziološkom otopinom bilo je od presudne važnosti za uspješnu provedbu ove metode (Runje i Cvrtila, 2006.). Primjena ELISA analize koristi se kod autentifikacije proizvoda od mesa, mliječnih proizvoda i proizvoda od ribe (Shibahara i sur., 2013.). Osim toga, može detektirati prisutnost genetski modificiranih organizama (Hsieh i sur., 2014.). Analiza pomoću ELISA metode može biti indirektna ukoliko se koriste dva antitijela od kojih je jedan specifičan za antigen i drugi je vezano $s$ enzimom. Upravo je antitijelo vezano s proteinom odgovorno za provedbu reakcije i stvaranje fluorescentnog signala. Izravna, odnosno sendvič vezana ELISA metoda odnosi se na drugi način analize tijekom koje je antigen između dva antitijela. Funkcija antitijela u ovom tipu reakcije je vezanje i detekcija antigena. Upravo antitijelo odgovorno za detekciju dovodi do nastanka biokemijske reakcije (Asensio i sur., 2008.).

\section{Zaključak}

Autentifikacija proizvoda je ključan čimbenik zaštite proizvoda te razdvajanja tradicionalnih proizvoda od patvorenih. Iako se i dalje koriste tradicionalne metode analize, razvoj novih metoda kao što su genomika i proteomika uspješno nadopunjuju već postojeće metode čime osiguravaju veću vjerodostojnost dobivenih rezultata analize. Analitičke metode koje se primjenjuju u postupcima autentifikacije proizvoda trenutno pružaju pouzdane podatke no očekuje se daljnji napredak u vidu proteomskih i kemometrijskih analiza.

\section{LITERATURA}

1. Ali, M.E., M. Kashif, K. Uddin, U. Hashim, S. Mustafa, X.B.C. Man (2012.): Species authentication methods in foods and feeds: the present, past, and future of halal forensics. Food Analytical Methods 5 (5): 935-955.

2. Ali, M.A., G. Gyulai, N. Hidvegi, B. Kerti, F.M. Al Hemaid, A.K. Pandey, J. Lee (2014.): The changing epitome of species identification-DNA barcoding. Saudi journal of biological sciences 21 (3): 204231.

3. Asensio, L., I. González, T. García, R. Martín (2008.): Determination of food authenticity by enzyme-linked immunosorbent assay (ELISA). Food Control 19 (1): 1-8. 
4. Ballin, N.Z. (2010.): Authentication of meat and meat products. Meat Science 86 (3): 577-587.

5. Corrado, G. (2016.): Advances in DNA typing in the agro-food supply chain. Trends in Food Science \& Technology 52: 80-89.

6. Crooijmans, R.P.M.A., M. San Cristobal, X. Hui, N. Li, M.A.M. Groenen (2008.): Biodiversity of pig breeds from China and Europe estimated from pooled DNA samples: differences in microsatellite variation between two areas of domestication. Genetics Selection Evolution 40: 103-128.

7. Danezis, G.P., A.S. Tsagkaris, V. Brusic, C.A. Georgiou (2016.): Food authentication: state of the art and prospects. Current Opinion in Food Science 10: 22-31.

8. Di Stefano, V, G. Avellone, D. Bongiorno, V. Cunsolo, V. Muccilli, S. Sforza, A. Dossena, L. Drahos, K. Vékey (2012.): Applications of liquid chromatography-mass spectrome try for food analysis. Journal of Chromatography A 1259: 74-85

9. Downey, G. (1996.): Authentication of food and food ingredients by near infrared spectroscopy. Journal of Near Infrared Spectroscopy 4: 47-62.

10. Uredba vijeća (EZ) br. 510/2006 od 20. ožujka 2006. o zaštiti oznaka zemljopisnog podrijetla i oznaka izvornosti poljoprivrednih i prehrambenih proizvoda

11. Fanali, S., P.R. Haddad, C. Poole, M.L. Riekkola (2017.): Liquid chromatography: fundamentals and instrumentation. Elsevier.

12. Farag, M. R., M. Alagawany, M. Abd El-Hack, R. Tiwari, K. Dhama (2015.): Identification of different animal species in meat and meat products: trends and advances. Journal of Animal and Veterinary Advances 3 (6): 334-346.

13. Fernández, A., E. Fabuel, E. Alves, C. Rodriguez, L. Silió, C. Óvilo (2004.): DNA tests based on coat colour genes for authentication of the raw material of meat products from Iberian pigs. Journal of the Science of Food and Agriculture 84 (14): 1855-1860.

14. Fontanesi, L. (2009.): Genetic authentication and traceability of food products of animal origin: new developments and perspectives. Italian Journal of Animal Science 8 (2): 9-18.

15. Fontanesi, L., A. Ribani, E. Scotti, N. Velickovic (2014.): Differentiation of meat from European wild boars and domestic pigs using polymorphisms in the MC1R and NR6A1 genes. Meat Science 98: 781-784.

16. Fontanesi, L., E. Scotti, M. Gallo, L.N. Costa, S. Dall'Olio (2016.): Authentication of "mono-breed" pork products: Identification of a coat colour gene marker in Cinta Senese pigs useful to this purpose. Livestock Science 184: 71-77.

17. Galtier, N., B. Nabholz, S. Glémin, G. Hurst (2009.): Mitochondrial DNA as a marker of molecular diversity: a reappraisal. Molecular Ecology 18: 4541-4550.

18. Hsieh, Y.H.P., J.A. Ofori (2014.): Detection of horse meat contamination in raw and heatprocessed meat products. Journal of agricultural and food chemistry 62 (52): 12536-12544.

19. Hsieh, M.K., P.Y. Shih, C.F. Wei, T.W. Vickroy, C.C. Chou (2015.): Detection of undeclared animal by-products in commercial canine canned foods: Comparative analyses by ELISA and PCR-RFLP coupled with slab gel electrophoresis or capillary gel electrophoresis. Journal of the Science of Food and Agriculture 96 (5): 1659-65.

20. Ibáñez, A.B., S. Bauer (2014.): Analytical method for the determination of organic acids in dilute acid pretreated biomass hydrolysate by liquid chromatography-time-of-flight mass spectrometry. Biotechnology for biofuel, 7 (1): 1. 
21. Kocher, T. D., W.K. Thomas, A. Meyer, S.V. Edwards, S. Pääbo, F.X. Villablanca, A.C. Wilson (1989.): Dynamics of mitochondrial DNA evolution in animals: amplification and sequencing with conserved primers. Proceedings of the National Academy of Sciences 86 (16): 6196-6200.

22. Kumar, D., S.P. Singh, N.S. Karabasanavar, R. Singh, V. Umapathi (2014.): Authentication of beef, carabeef, chevon, mutton and pork by a PCR-RFLP assay of mitochondrial cytb gene. Journal of Food Science and Technology 51 (11): 3458-3463.

23. Lefkovits, I., B. Pernis (2014.): Immunological methods (Vol. 3). Elsevier.

24. Littlewood, A.B. (2013.): Gas chromatography: principles, techniques, and applications. Elsevier.

25. Meyer, V.R. (2013.): Practical high-performance liquid chromatography. John Wiley \& Sons.

26. Meurens, M., M. Lees (2003.): Spectrophotometric techniques. Food authenticity and Traceability 184-196.

27. MPS (2016.): Zaštićene oznake izvornosti (ZOI) - registrirane na EU razini / prijelazna nacionalna zaštita.

28. Murugaiah, C., H. Al-Talib, S. Radu (2015.): Forensics: Food Authentication Using MtDNA. Journal Nutrition Health Food Science 3: 1-10.

29. Ni'mah, A., A.D. Pratama, L.R. Kartikasari, B.S. Hertanto, M. Cahyadi (2016.): Detection of pork contamination in fresh and cooked beef using genetic marker mitochondrial-DNA cytochrome $b$ by duplex-p. Journal of the Indonesian Tropical Animal Agriculture 41 (1): 7-12.

30. Nielsen, S.S. (2010.): Phenol-sulfuric acid method for total carbohydrates. In Food Analysis Laboratory Manual (pp. 47-53). Springer US.

31. Pardo, E., T.I. Cavadía, I. Melendez (2015.): Genetic diversity of domestic pigs in Tierralta (Colombia) using microsatellites. Revista Colombiana de Ciencias Pecuarias 28 (3): 272-278.

32. Pravilnik o zaštićenim oznakama izvornosti, zaštićenim oznakama zemljopisnog podrijetla i zajamčeno tradicionalnim specijalitetima poljoprivrednih i prehrambenih proizvoda ( $\mathrm{NN}$ br. 65/15).

33. Reid, L.M., C.P. O'donnell, G. Downey (2006.): Recent technological advances for the determination of food authenticity. Trends in Food Science \& Technology 17 (7): 344-353.

34. Rodríguez-Ramírez, R., A.F. González-Córdova, B. Vallejo-Cordoba (2011.): Review: Authentication and traceability of foods from animal origin by polymerase chain reaction-based capillary electrophoresis. Analytica chimica acta 685 (2): 120-126.

35. Runje, M., Ž. Cvrtila (2006.): ELISA u analitici hrane. MESO: prvi hrvatski časopis o mesu 8 (2): 8995.

36. Saiki, R.K., S. Scharf, F. Faloona, K.B. Mullis, G.T. Horn, H.A. Erlich, N. Arnheim (1985.): Enzymatic amplification of b-globin genomic sequences and restriction site analysis for diagnosis of sickle cell anemia. Science 230 (4732): 1350-1354.

37. Sforza, S. (2013.): Food authentication using bioorganic molecules. DEStech Publications, Inc.

38. Shibahara, Y., Y. Uesaka, J. Wang, S. Yamada, K. Shiomi (2013.): A sensitive enzyme-linked immunosorbent assay for the determination of fish protein in processed foods. Food Chemistry 136 (2): 675-681.

39. Sumathi, G., G. Jeyasekaran, R.J. Shakila, B. Sivaraman, G. Arunkumar, U. Manimaran, D. Sukumar (2015.): Molecular identification of grouper species using PCR-RFLP technique. Food Control 51: 300-306. 
40. Sun, L., L. Chen, X. Sun, X. Du, Y. Yue, D. He, L. Ding (2009.): Analysis of sulfonamides in environmental water samples based on magnetic mixed hemimicelles solid-phase extraction coupled with HPLC-UV detection. Chemosphere 77(10): 1306-1312.

41. Sun, X., J.F. Chiu, Q.Y. He (2014.): Application of immobilized metal affinity chromatography in proteomics. Expert review of proteomics 2(5): 649-657.

42. Veselenak, R.L., A.L. Miller, G.N. Milligan, N. Bourne, R.B. Pyles (2015.): Development and utilization of a custom PCR array workflow: analysis of gene expression in mycoplasma genitalium and guinea pig (Cavia porcellus). Molecular Biotechnology 57(2): 172-183.

43. Weber, J.L., P. May (1989.): Abundant class of human DNA polymorphisms which can be typed using the polymerase chain reaction. American Journal of Human Genetics 44 (3): 388.

44. Wilkins, M.R., J.C. Sanchez, A.A. Gooley, R.D. Appel, I. Humphery-Smith, D.F. Hochstrasser, K.L. Williams (1996.): Progress with proteome projects: why all proteins expressed by a genome should be identified and how to do it. Biotechnology and Genetic Engineering Reviews 13(1): 1950.

45. Zakon o zaštićenim oznakama izvornosti, zaštićenim oznakama zemljopisnog podrijetla i zajamčeno tradicionalnim specijalitetima poljoprivrednih i prehrambenih proizvoda, NN br. $80 / 13,14 / 14,30 / 15$.

\section{APPLICATION OF ANALYTICAL METHODS FOR FOOD AUTHENTICATION}

\section{Summary}

Food Authentication is primarily used for testing the composition and origin of agricultural and food products. Croatia has a large number of agricultural and food products, which are due to the specific organoleptic, technological and nutritional specifics declared as high-value and they are protected by designation of origin, geographical indications and traditional specialties guaranteed. The implementation of the authentication procedure is multidisciplinary process which includes analytical methods combined with computer science, mathematics and statistics, all with the goal of achieving a more accurate and reliable information in order to make a conclusion about the origin and composition of the product. Public interest in the consumption of high-quality and safe food has led to a rapid development of methods for products authentication. The analytical approach to the analysis is divided in several categories related to the molecular analysis methods, chromatographic methods, immunological methods and spectroscopic methods. This paper describes the analytical methods used in the procedures of proving the origin, geographical indications or traditional specialties products.

Key words: authentication, analytical methods, protection of the products

Primljeno - Received: 28.11.2017.

Prihvaćeno - Accepted: 30.01.2018. 